\title{
Regulation and business power: the case of public transportation in Santiago (2007-2017)
}

\author{
Antoine Maillet 1 \\ Sebastián Carrasco ${ }^{2}$ \\ 1 Universidad de Chile / Instituto de Asuntos Públicos, Santiago, Chile \\ 2 Universidad Mayor, Santiago, Chile
}

Full understanding of regulatory processes requires taking into account their political dimension, until now rarely considered in public administration literature. The concept of 'business power' developed in comparative political economy contributes to comprehend this dimension. The case study of the transport system "Transantiago" presented in this article demonstrates that businesses' structural power is of special interest. The process tracing applied to the case of Transantiago, shows that the inability of the authorities to impose their preferences is mainly due to the structural constraints they faced. The effects of this inability are observed in the bidding process and in the phase of implementation of the regulation process.

Keywords: regulation; regulatory process; concession; business power; public transportation.

\section{Regulação e poder de negócios: 0 caso do transporte público em Santiago (2007-2017)}

O pleno entendimento dos processos regulatórios exige considerar sua dimensão política, até agora raramente considerada na literatura da administração pública. O conceito de poder de negócio desenvolvido pela economia política contribui para esse objetivo. Como demonstra o estudo de caso do Transantiago, o poder estrutural dos negócios é de especial interesse. O process tracing aplicado ao caso desse sistema de transporte, inaugurado em 2007, mostra que a incapacidade das autoridades em impor suas preferências se deve principalmente às restrições estruturais que enfrentam, cujos efeitos variam na fase de leilão e implementação do processo de regulação.

Palavras-chave: regulação; processo regulatório; concessão; poder de negócio; transporte público.

\section{Regulación y poder empresarial: el caso del transporte público en Santiago (2007-2017)}

Una plena comprensión de los procesos regulatorios requiere tomar en cuenta su dimensión política, hasta ahora escasamente considerada en la literatura de administración pública. A este objetivo contribuye el concepto de poder empresarial que ha desarrollado la economía política. Como lo demuestra el estudio de caso de Transantiago, resulta de especial interés la vertiente estructural del poder empresarial. El process tracing aplicado al caso de este sistema de transporte demuestra que la incapacidad de las autoridades de imponer sus preferencias se debe principalmente a las restricciones estructurales que enfrentan, cuyos efectos se manifiestan de manera distinta en la etapa de adjudicación de la licitación y en la fase de implementación.

Palabras-clave: regulación; proceso regulatorio; concesión; poder empresarial; transporte público.

\footnotetext{
DOI: http://dx.doi.org/10.1590/0034-761220180079x

Article received on March 16, 2018 accepted on October 31, 2018.

[Translated version] Note: All quotes in English translated by this article's translator.

The authors appreciate the valuable comments of Aldo Madariaga and Bastián González-Bustamante in preliminary versions of this work, as well as the acute analyzes performed by academics of the Housing Institute of Universidad de Chile in a seminar in May 2018. In addition, both authors appreciate the support of FONDECYT (CONICYT / FONDECYT / 1190070) and Centro de Estudios de Conflicto y Cohesión Social (CONICYT / FONDAP / 15130009).
} 


\section{INTRODUCTION}

Although with the development of the concept of governance the study of regulation has taken a greater variety of actors into account (Baldwin, Cave, \& Lodge, 2010), in public administration the predominant focus is still on the actions of authorities, in particular on suitable designs for achieving a quality regulatory process (Engel, Fisher, \& Galetovic, 2010) and on the risks of opportunistic government behaviors (Bitran et al., 2013). The repudiation of capture- from this perspective any regulation made in concert with or under pressure from economic actors would be considered captured-is just the reverse face of this bias toward a unilateral focus on the power of authority. Undoubtedly, in a process of regulation the relations between political authorities and certain economic groups carry a risk of the former being captured by the latter (Stigler, 1971). But the state can also establish a virtuous relationship with private actors, one that generates greater efficiency in the provision of public services while allowing it to preserve its autonomy at the same time (Evans, 1996). Even recognizing the importance of the actors with formal responsibility for the design of regulation, the complexity of decision-making in the public sphere generally makes necessary to incorporate other actors in empirical analyses of how the latter is achieved (Dente \& Subirats, 2014). In accounting for the powerful constraints that limit the authority's sovereign decisions in regulatory processes, this article invites the reader to consider the concept of business power developed in political economy (Hacker \& Pierson, 2002), which contributes to a better understanding of the political dimension of regulation, and in particular of tendering mechanisms.

This reflection has its empirical roots in a regulatory process that was paradigmatic on a continental scale, that of public transport in Santiago, Chile's capital. In February 2007, the Transantiago system, involving the creation of a new regulated public transport market, was launched (Ureta, 2015). Different business units were offered for tender, leaving national and foreign companies in charge of them (Maillet, 2015). Numerous operating problems, which quickly led to political difficulties (Mardones, 2008; Olavarría, 2013), gave rise to an ongoing dispute between transport operators and authorities - mainly the Minister of Transport and Telecommunications-mainly focused on the contracts, their provisions and how to monitor compliance. Since the initial crisis in 2007 until the unsuccessful new call for tenders in 2018, successive ministers have wanted to modify signed contracts or even declare them to have lapsed. However, neither continuous media exposure nor the cross-party rejection of the system have been enough to completely reverse its operating problems. How did the operators of Transantiago resist this pressure? Expressed more conceptually, how to explain the authorities' difficulties in imposing their preferences in the regulatory process?

Political economy offers one possible answer to this empirical question and its theoretical corollary-namely the concept of business power, the influence exercised by business actors in the political process (Culpepper, 2011; Hacker \& Pierson, 2002). Generically, business power is expressed in two ways. The first, instrumental power, consists of the organized pressure of economic actors on politics. The second, structural power, is manifested through business actors' actual economic weight, especially their ability to halt investments if concerned about policies implemented (Fairfield, 
2015a). Despite the explanatory potential of this literature, it has still to be considered in public administration and public policy studies. Based on a case study of Transantiago, then, our aim in this article is to demonstrate the analytical contribution this conceptual tool can make to the study of regulatory processes.

The main research hypothesis arising from this question is that business power exercised by the operators played a fundamental role in the political authority's inability to impose its preferences in the regulatory process. By this term we understand the relationship established between public and private actors by a service's being offered for tender, including both the design of the competitive processes for the award of contracts, as well as their implementation. To develop this hypothesis, we present below the theoretical framework of the study. Then we describe the case study and consider alternative hypotheses. All of these are evaluated through process tracing of the case. In conclusion, we discuss the general implications of the results of this study.

\section{INCORPORATING BUSINESS POWER IN DEVELOPING THE POLITICAL DIMENSION OF THE REGULATORY PROCESS. TOWARDS A MORE COMPLEX VIEW}

\subsection{Regulation and contractualization: the traditional perspective and its gaps}

First, we must define what is meant by regulation in this article. Traditionally, it has been considered as "the sustained and focused control exercised by a public agency over activities that are valued by a community" (Selznick, 1985, as cited in Baldwin et al., 2010 p.12), but its definition has been extended to "the intentional use of authority to affect behaviour of a different party according to set standards, involving instruments of information-gathering and behaviour modification" (Black, 2001, as cited in Baldwin et al., 2010 p.12). As can be seen, the traditional definition had a very restricted focus on control, and this implied a limited number of policy instruments. With the updated definition, many incentive-based instruments come to be part of regulation, in a change of logic that has been viewed as marking a transition in the state's role from "rowing" to "steering" (Osborne \& Gaebler, 1992). Every mechanism of delegation and contractualization is part of the latter, as are the calls for tender and their later renegotiation, with which this article is concerned.

In general, public procurement is the main mechanism used to formalize these relations between the state and private actors (Mukhopadhyay, 2011; Bhagat, 2017). In Chile, these contracts are covered by the legal concept of the tender, which is the procedure by which a private party bids to provide a service or public good. The tender has become a common instrument in the introduction of competition into the regulation or acquisition of goods and services offered by private entities; it takes place when there is only one buyer (the public sector) and multiple suppliers, either in contexts of imperfect competition or natural monopolies, as well as in regulated industries, or in small markets with imperfect information (Menezes, Pitchford, \& Wait, 2003). However, in general, calls for tenders have difficulty in generating competition. This is a difficult operation in which potential problems may emerge in the subsequent relationship. However, in an effort to establish norms, the literature has also tended to stipulate an optimal design for a contract. Authors such as Engel et al.(2010) point out the importance of balancing demand risk, fee distortions and the opportunity 
cost of public funds, generating a minimum and maximum guarantee of income. The big difficulty that must be resolved in the design of a contract is to establish its level of flexibility. Such flexibility can oscillate between very flexible designs which can lead to opportunistic renegotiation, or rigid designs that can sacrifice opportunities for renegotiating in the public interest. Finding a suitable mid-point between the two extremes is essential (Athias \& Saussier, 2007).

Despite the technical aspects just indicated, both bids and contract renegotiation are processes in which political variables play a fundamental role (Bitrán et al., 2013), but they are not typically approached from this angle. The literature recognizes, it is true, the tension that exists between the interests of private entities and the government sector's need for public value creation, leading to multiple types of public-private partnership (Bovaird, 2006; Wettenhall, 2003). However, it has not explored exhaustively the conflicting relationships that underlie them.

A purely economistic or public management approach to understanding the dynamics of contracts has therefore clear limitations. For example, the evidence shows that, although government agents may have powerful tools to enforce the execution of contracts, especially in regard to the imposition of sanctions, such tools are usually not used (Girth, 2012). Thus contractual obligations are not enforced, even though it is technically feasible and legally viable to do so. The original contribution of this study is to address the dynamics of contractualization from an analytical viewpoint different from the predominant ones.

\subsection{Towards a political perspective: the contribution of business power to the study of regulatory process dynamics}

In the framework of regulatory policies, regulatory agencies will never be completely autonomous or fully captured, but their behavior will be determined by the interactions they have with other social actors (Gilardi \& Maggetti, 2011). Therefore, to understand the regulatory process means developing a perspective that emphasizes the political dimension of typically conflictive processes by incorporating other actors in the analysis; especially business actors, as the entities subject to regulation in the regulatory process. Political economy provides powerful analytical tools for this purpose. In particular, the literature on business power seems fundamental in explaining conflictual dynamics of this kind between public and business actors. The specific elements of this theoretical perspective are detailed below.

In the literature on business power, the business sector can exert its political influence through two main types of power. On the one hand, there is structural power, which refers to the credible threat perceived by policymakers that a reform in the political sphere will reduce private investment, negatively affecting economic aggregates (Fairfield, 2015a). Based on this, the structural nature of this power is a corollary of the privileged economic position that private sector agents occupy in capitalist systems (Fairfield, 2015a). Although establishing how this power operates in the political arena is complicated (Culpepper, 2015), it is relevant to note that it is closely linked to the relative weight of private enterprise in a specific economic sector, in relation to the state's role in the economy (Fairfield, 2015a). To the degree that the state is a major actor in the economy, the structural power of business will be weak. However, in capitalist economies, as is well known, it is firms that produce goods, create 
jobs and decide when, where, and how to invest (Lindblom, 1982), which makes structural power a permanent threat in this type of system. In this sense, in the exercise of structural power a central role is played by policy-makers' perceptions and expectations regarding the reaction of entrepreneurs to certain decisions (Bell \& Hindmoor, 2013).

Therefore, in general, the literature on structural power considers the threat that public policies may represent for company investment to be a central concern of decision makers (Fairfield, 2015a). Within the framework of regulatory activities, where autonomous agencies regulate business activities (Jordana \& Levi-Faur, 2005) and intervene in the economic sphere to direct private action towards the realization of public objectives (Christensen \& Lægreid, 2006), the state faces a dilemma, between the need to regulate private entities while at the same time seeking not to interfere with their investment in the provision of services of value to the community. This analytical perspective is especially revealing in the case of Transantiago. The need to attract private investment to get the service up and running may mean that the institutional rules established do not make sufficient demands on the companies to ensure that the system works efficiently. In the framework of a bidding process, this means introducing incentives into the contracts to attract the participation of bidders.

Thus, structural power has particular effects on the processes of policy formulation, in which the decisions made are constrained by the need to encourage investment by private actors (Fairfield, 2015a). However, unlike what is established in the traditional literature on business power, we suggest that structural power is not expressed exclusively in processes of policy formulation where there is a need to maintain and/or attract private investment. On the contrary, we maintain that structural power can also be observed, but in a different guise, during the implementation phase when the authorities execute the regulatory instruments against the companies. In the implementation phase, the threat of the firms' bankruptcy and resulting paralysis of service delivery can result in the regulatory instruments not being applied with the full force of the law. In short, the decisions of the authorities are not only constrained by the need to safeguard investment, but also to ensure that these firms do not cease operations. In the case under study, the risk of the transport service being interrupted would cause the authorities to be cautious in their application of the contractual provisions against the companies. This constitutes a form of original structural power typical of regulatory processes that deserves greater attention by those interested in these phenomena.

In contrast to structural power, instrumental power derives from political resources that are deliberately constructed to influence public policy in a much more effective way (Fairfield, 2015a). These resources can take different forms. Among the instruments business groups use to influence policies are the links they establish with political parties; institutionalized consultations, expressed mainly in formal meetings with authorities and negotiating tables; the recruitment of business representatives to government positions; informal links of different types, such as family and professional connections, and business group pacts to coordinate actions vis-à-vis the authority. Technical expertise, access to media, and money (with which political campaigns can be financed, for example) complete this list (Fairfield, 2015a). In the case of regulation, these mechanisms can be used to influence the regulator's decisions. The specific strategies companies devise depend 
on the existing regulatory environment (Henson \& Hooker, 2001, as cited in Gilardi \& Maggetti, 2011). Hence the importance of understanding the actions undertaken by companies based on the instrumental power they have. In the case of transport, it would imply seeking to control contracts and leading the renegotiation processes so that the regulatory policy corresponds to company preferences.

As against the business power perspective, another of the study's alternative hypotheses refers to the institutional weaknesses of the authority as an explanatory factor of contracts and decisions. In general terms, this perspective relates theoretically to the concept of state capacity. Thus, low state capacity would lead to institutional weaknesses. According to the classic literature on the subject, state capacity is expressed when public institutions manage to achieve their goals, especially when there is opposition from sectors of civil society (Sckocpol, 1985). In this sense, public policy choices regarding market regulation would be affected by endogenous factors related to state capacity (Besley \& Persson, 2009). In synthesis, this capacity would be expressed mainly in the coercive, fiscal and administrative elements of government (Cingolani, 2013). Empirically, these dimensions can be expressed in the technical-political skills of political authorities in enforcing their wishes (Centeno, 2002), the degree of professionalization of the bureaucracy and its political independence in making decisions on policy-implementation processes (Peters, 1996) and the ability to collect taxes, with the consequent use of these resources to provide public goods and make transfers (Besley \& Persson, 2008), according to the objectives defined.

These different concepts - operationalized in the next section - form the analytical framework of the case study developed below.

\section{CASE STUDY DESIGN}

From its beginning until the present day, Transantiago has undergone numerous modifications in order to improve the transport service. As a result, the government has been unable to fully achieve the objectives it set itself of having a "transport system (...) better than any other country" (Transantiago coordinator, as cited in Maillet, 2008). To explain why the government has been unable to impose its preferences, we propose to treat Transantiago as a case study, using a process tracing methodology (Bennett \& Checkel, 2015; Bril, Maillet, \& Mayaux, 2017; Trampusch \& Palier, 2016), which allows us to establish causal relationships between different variables to test the hypotheses suggested.

The main research hypothesis is that business power exercised by entrepreneurs played a fundamental role in the political authority's inability to impose its preferences on these operators. Viewed from this perspective, the instrumental and structural power strategies exercised by companies are differentiated within the framework of this sectoral policy. An alternative hypothesis that is explored to explain the inability of the authorities to impose their preferences rests on possible deficiencies of the authority itself. Certain characteristics of public bodies and authorities could be the reason why these actors fail to implement decisions that are consistent with their preferences for public transport in the capital. The main expressions of this deficiency could be issues like political weakness, deficits of technical capacity and suitability, or budgetary constraints. The answer is not to choose between the hypotheses, but rather-as case studies usually allow-to identify and 
rank in importance the factors determining the outcome of interest in a logic of complex causality (Goertz \& Mahoney, 2012).

To test these research hypotheses, a narrative has been built, based on copious and diverse empirical material. With the help of a research team, ${ }^{1}$ information from 761 press articles in Diario Financiero, a national newspaper specializing in economic and regulatory issues, was systematized. The selected articles included all entries in the newspaper containing the term "Transantiago" between 2008 and 2018. In addition, 16 interviews were conducted with key public and private sector actors, as well as two public forums with experts from various disciplines. ${ }^{2}$ The interviewees included former ministers, undersecretaries, senior public managers, transport entrepreneurs, and transport experts belonging to different national universities. The information thus collected was complemented by other press sources, official government documents, journalistic investigations, technical reports, laws and discussions of the legislative bills that were debated in the National Congress.

The table below summarizes the hypotheses and specifies the observable implications (Bril et al., 2017).

\section{TABLE $1 \quad$ HYPOTHESIS, OPERATION AND OBSERVABLE IMPLICATIONS}

\begin{tabular}{|c|c|c|}
\hline Hypothesis & Operationalization ${ }^{3}$ & Observable implications \\
\hline \multirow[t]{4}{*}{ H1a. Operators' instrumental power } & Cohesion & $\begin{array}{l}\text { Collaboration between operators strengthens } \\
\text { them vis-a-vis the authority. }\end{array}$ \\
\hline & Technical expertise & $\begin{array}{l}\text { Operators provide public agencies with } \\
\text { technical expertise, making them dependent. }\end{array}$ \\
\hline & Access to media & Operators enjoy a good public image \\
\hline & $\begin{array}{l}\text { Informal links with authorities and } \\
\text { parties- Revolving door }\end{array}$ & $\begin{array}{c}\text { Private and public sector actors share } \\
\text { personal, professional and/or political } \\
\text { networks, which allow the former to influence } \\
\text { the latter. }\end{array}$ \\
\hline \multirow[t]{2}{*}{ H1b. Operators' structural power } & Suspension of future investments & $\begin{array}{l}\text { Entrepreneurs threaten to abandon the } \\
\text { activity (or the authority perceives that they } \\
\text { may do so). }\end{array}$ \\
\hline & Bankruptcy risks & $\begin{array}{l}\text { The contractual provisions place the } \\
\text { companies at risk of bankruptcy, which would } \\
\text { threaten the continuity of the service. }\end{array}$ \\
\hline
\end{tabular}

${ }^{1}$ The research team consisted of University of Chile public administration students Alessandra Altamirano, Camila Flores, Pablo Mancilla and Matías Silva.

2 "Hybrid neoliberalism and public policies," October 17, 2017; "New call for Transantiago tenders: where are we coming from and where are we going?” INAP, University of Chile, January 6, 2018. 


\begin{tabular}{|c|c|c|}
\hline Hypothesis & Operationalization ${ }^{3}$ & Observable implications \\
\hline \multirow[t]{3}{*}{$\begin{array}{l}\text { H2. Deficiencies in public agencies and } \\
\text { the authority }\end{array}$} & $\begin{array}{l}\text { Deficit of technical capacity/ } \\
\text { suitability }\end{array}$ & $\begin{array}{l}\text { The public sector lacks sufficient expert } \\
\text { knowledge to direct the regulatory process. }\end{array}$ \\
\hline & Political weakness & $\begin{array}{l}\text { The current authority is perceived as weak by } \\
\text { the other actors. }\end{array}$ \\
\hline & Budgetary constraints & $\begin{array}{l}\text { Tight budget restrictions limit the public } \\
\text { sector's negotiating power. }\end{array}$ \\
\hline
\end{tabular}

Source: Elaborated by the authors.

To test the hypotheses empirically, the course of public transport policy in Santiago over a tenyear period is analysed, and the main landmarks in the relation between authorities and transport companies during the regulation of Transantiago are discussed.

\section{OF CONFLICTS AND RE-NEGOTIATIONS: TEN YEARS OF TRANSANTIAGO}

\subsection{Adjudication and beginnings of Transantiago: in the shadow of structural power}

The intention behind Transantiago was to provide the whole city with a modern, sustainable and fully integrated public transport system, structured through the instrument of tenders (Figueroa \& Forray, 2011). However, from its formulation it was noticeable that the main concern of the designers of the capital's transport system was to achieve the investment of private firms. The need to attract enough investors into the transport business - to ensure that there were enough competitors for the system to operate-led decision makers to establish contractual measures in the bidding process that were directly to the benefit of the entrepreneurs. Specifically, at the end of 2003 the Bidding Rules for Road Use were presented. Their main objective was to provide security to investors, neglecting aspects of service provision (Espacio Público, 2017). Various deficiencies in the service delivery later attested to this issue. These elements can be observed in comments to the authors by a former transport minister:

The original contract was a contract conceived to attract investors. And it was not conceived with the passengers in mind. So the system was so criticised when it was designed that the business world did not want to get involved, they felt that they were getting into something that was poorly designed (interview with former minister $\mathrm{n}^{\circ} 2$ ).

Thus, a first hint of the structural power that companies have in the regulatory relationship appears in this statement. Limits to the very formulation and award of the contract were determined by the perceived risk of an absence of bidders. To avoid this, from the beginning an attractive contract for "the investors" had to be designed. Structural power, then had a powerful influence on the first adjudication process. In theoretical terms, structural power was observable here in its most classical

\footnotetext{
3 "Institutionalized consultation" was not considered, as there are no examples of it in the Chilean transport sector.
} 
form. That is to say, from the very first moment the authorities intuited that private sector investment might be scarce, and were worried (Hacker \& Pierson, 2002). Consequently, this concern shaped their design of the instruments of regulatory policy.

At the time of the tender adjudication in 2004, 10 companies had signed the contracts, a novelty being the entry of Colombian investors who were awarded one of the five trunk contracts, while the other business units were acquired by Chilean operators belonging to the old transport system (Gómez-Lobo, 2007).

\subsection{Structural power in the system's regulation and the transport authorities' limited powers of intervention (2007-2014)}

Transantiago's first days were chaotic and caused huge economic and political impact in the country (Mardones, 2008). For this reason, the then-transport minister Sergio Espejo's resignation came as no surprise, since Transantiago's operation had brought various difficulties with it. Yet all transport ministers from this stage on have had important academic credentials as well as long experience in the public and private sectors and the academic world. As can be seen in the table below which summarizes the career details of these important political actors, this was clearly not a question of weak authorities.

\section{TABLE 2 TRANSPORT MINISTERS IN CHILE (2007-2018)}

\begin{tabular}{|c|c|c|c|c|c|}
\hline Minister & Profession & $\begin{array}{c}\text { Academic } \\
\text { qualifications }\end{array}$ & \multicolumn{2}{|c|}{ Period as minister } & Prior career \\
\hline René Cortázar & $\begin{array}{c}\text { Business } \\
\text { administrator }\end{array}$ & $\mathrm{PhD}$ & 27-03-2007 & $10-03-2010$ & Minister; company director \\
\hline Felipe Morandé & $\begin{array}{c}\text { Business } \\
\text { administrator }\end{array}$ & $\mathrm{PhD}$ & $11-03-2010$ & $16-01-2011$ & $\begin{array}{c}\text { Academic; consultant for } \\
\text { international organizations; } \\
\text { chief economist, Central Bank }\end{array}$ \\
\hline $\begin{array}{l}\text { Pedro Pablo } \\
\text { Errazuriz }\end{array}$ & $\begin{array}{c}\text { Business } \\
\text { administrator }\end{array}$ & Masters & $17-01-2011$ & $10-03-2014$ & $\begin{array}{l}\text { Company manager, including } \\
\text { transport companies (LAN) }\end{array}$ \\
\hline $\begin{array}{l}\text { Andrés Gómez- } \\
\qquad \text { Lobo }\end{array}$ & $\begin{array}{c}\text { Business } \\
\text { administrator }\end{array}$ & $\mathrm{PhD}$ & 11-03-2014 & 13-03-2017 & $\begin{array}{l}\text { Researcher; advisor; consultant } \\
\text { for international organizations, } \\
\text { and director of the public } \\
\text { company, Metro }\end{array}$ \\
\hline Paola Tapia & Attorney & Masters & $14-03-2017$ & 11-03-2018 & $\begin{array}{c}\text { Top posts in public } \\
\text { administration, ministerial } \\
\text { advisor }\end{array}$ \\
\hline
\end{tabular}

Source: Elaborated by the authors. 
The minister in charge of the first phase of implementation, René Cortázar-who was put in charge of solving the situation and enjoyed full powers and cross-party support-played a key role in the first instances of contract renegotiation. His technical and political ability in executing different policy processes, coupled with the powers delegated by the president, gave Cortázar significant powers in the use of coercive measures (Cingolani, 2013).

At the moment of his arrival, the deficiencies in the operation were very serious and in large part attributable to the opportunism of operators. Since the contracts allowed this to happen, their renegotiation was a priority. In the first place, the renegotiation focused on addressing problems arising from the number of buses in the streets, the reduction of fare evasion, and the attention of passengers, since the owners of the lines under concession enjoyed conditions that allowed them to profit without complying with the required number of buses, and faced usually insignificant fines (Ramírez \& Minay, 2007). To achieve his objectives, Cortázar combined incentives ("carrot") with pressure ("stick") in his dealings with the Transantiago companies, thereby becoming more confrontational in his attitude. As he himself wrote later:

There were no more "carrots" (...) there was only the "stick", which consisted of using the state's capacity to terminate the concession of any operator that was not adequately fulfilling its contract (Cortázar, 2015, p. 73).

The way the situation was characterized in the preceding paragraphs seems to contradict the literature on business power. Typically, the Chilean business elite has been described as a group that has developed important sources of instrumental power (Fairfield, 2015b). However, the specific contextual characteristics that were discernible at that time hindered the use of instrumental power. The users' general disapproval of the system left companies with few opportunities to present themselves as victims of state abuse. Even so, the process was "a drawn out business, because the companies fled the negotiation, the companies did not want to negotiate" (interview with business leader $\mathrm{n}^{\circ} 2$ ), while the government insisted that the system's main flaws lay in the contracts.

In this context, with the expiry in 2008 of the contract for zone G, for which the company Buses Gran Santiago was responsible, the minister found a way to exert pressure. In this case, use of the "stick" affected a small company which operated around 200 buses, as compared to the 5000 included in the system. A similar dynamic would later be observed during the presidency of Sebastián Piñera (2010-2014). The minister of transport of this period, Felipe Morandé, terminated a contract with Transaraucaria, one of the operating companies of Transantiago, for breaching its terms. However, this measure again affected a very small company, making it evident that these powers had only been used with companies that did not present any risk of paralyzing the system. The companies, still unpopular and operating opportunistically, held onto their major negotiating lever: the risk of bringing the city to a standstill. After all, "too extreme, too draconian sanctions in the end are not possible to implement" (interview with former minister No. 3).

Undoubtedly, this problem is an example of companies' structural power. The huge political risk of a paralysis of the service meant that the expiry of contracts could only be applied in specific instances and against small companies. This source of structural power is deployed in the specific context of the operation and implementation of regulatory policies; it differs from the structural power manifested in the adjudication of the system, as we saw in the previous section. Although the major operators 
had also breached their contracts on more than one occasion, the instruments applied against them did not involve a measure as drastic as termination. The impossibility of applying sanctions effectively was the greatest difficulty faced by the ministry team in the Piñera administration in attempting to restructure the system in the desired direction. As expressed by one actor in the process:

A problem with the design of Transantiago is that the [operating] zones are very large, so if an operator says" No, I will not accept that and I'll leave," you could imagine the scale of the problem, you're left with a whole area of Santiago without public transport. A tragedy! (Interview with top public official $\left.\mathrm{n}^{\circ} 1\right)$.

To face this situation, a bill was drawn up aiming to grant the executive greater powers to control and supervise the operating companies, in addition to renegotiating or terminating contracts when necessary. The processing of the law was particularly fast, despite the fact that the government did not have a majority in Congress, and it was promulgated in January 2011 (Law 20,504). Again, no concerted actions by operators to try to influence the process were reported. The law under discussion, by granting greater powers to the authorities and subjecting the transport companies to greater control, was clearly against the latter's interests. Again, there is no evidence of their exercise of instrumental power.

With a change of cabinet in 2011, Pedro Pablo Errázuriz took over the ministry portfolio. Using the new powers granted by Law 20,504, Errázuriz renegotiated and in 2012 obtained new contracts in which the notion of feeder and backbone routes was eliminated, while specific business units were assigned to the operators, and responsibility for fare evasion transferred. The process began with meetings between the ministry and the companies, which at first were largely unproductive. This triggered the need to strengthen the ministry teams, to put an end to some asymmetry at the moment of negotiations (interview with former minister No. 2). Law 20,504 also played a key role in the negotiation process since, as one interviewee observed, "with the tool in hand, it was like negotiating with a pistol on the table, otherwise there would have been no incentive for operators to want to change contracts. I mean, they had a guaranteed demand!" (Interview with senior public official n ${ }^{\circ} 1$ ).

Errázuriz chose to conduct separate negotiations with each company. He first reached an agreement with three large companies, Vule, Metbus and Subus, each of which were offered the choice of one of the feeder routes to be reassigned. Then, the rest of the operators had to follow the same dynamic. Again, they demonstrated no cohesion. On this occasion, the state was able to get closer to its preferences by intensifying pressure on the entrepreneurs, who had to cede part of the benefits they had obtained in the original contracts. Thus, showing their technical and political negotiating abilities, the authority was able to secure certain changes in the system's functioning that negatively affected the companies, (Centeno, 2002; Peters, 1996).

In conclusion, within the framework of Transantiago, the relationships that developed between public and private actors in the implementation of regulatory policy resulted in the authorities being partially able to impose their preferences. To explain this, the empirical evidence provides elements that support the hypothesis of structural power, since there were no major manifestations of instrumental business power, nor of public actors weakness. In sum, the manner in which structural power acts was clearly visible at this stage. Although the authority advanced in introducing tougher regulatory measures for the companies, they were not applied with all the firmness the existing state 
capacity allowed. The ultimate explanation of this phenomenon is that policy-makers' decisions in this area are constrained by the expectations they have of private actors' behavior (Fairfield, 2015b), and of the functioning of the system itself. Since they were unable to take the risk of the service being interrupted, the application of tough sanctions by the ministers was not a viable option even though all the elements were in their favor.

As in the adjudication stage, the implementation of the regulatory policy was powerfully constrained by the operators' structural power. However, the type of power between one stage and another varied considerably. While in the tender process the state had a central interest in attracting bidders and boosting investment, in the implementation phase there was a concern about the companies' bankruptcy risk, which could lead to paralysis of the service. For state actors, this was undoubtedly a scenario to be avoided at all costs. For all their atomization and weakness, the bus companies were not particularly affected by the changes introduced by the authority, given their own structural power in the area of concessions.

\subsection{Between bankruptcies and agreements: the (failed) construction of instrumental transport power}

In the above sections, the technical and political abilities demonstrated by the authorities in the field of transport regulation have been discussed, as well as the structural power that the transport companies have accumulated in dealing with the regulatory policy under study. However, part of the study's hypothesis refers to the fate of attempts by the Transantiago entrepreneurs to build instrumental power, and to this we now turn. Specifically, it has been documented that the entrepreneurs did make efforts to build cohesion in their ranks, this being one of the traditional attributes of instrumental power (Álamos, 2017).

After the separate negotiations conducted with Errázuriz, the businessmen reacted by forming in December 2013 an Association of Surface Urban Transport Concessionaires (ACTUS, in its Spanish acronym), a union (gremio) that included most of the Transantiago operators. This grouping sought to represent the concessionaires in their dealings with public and private institutions, with a technical team able to collaborate in finding solutions to Transantiago. For the first time in six years of operation, the operating companies formally collaborated to act with a united voice in negotiations with the authority. In pursuit of greater instrumental power, the organization also established certain informal links with the public sector, through the recruitment of political personalities, notably with the incorporation of Victor Barrueto, former congressman and head of the Metropolitan Region, as its executive director. In addition, it attempted to build a channel for technical cooperation with the ministry, which materialized in studies presented to the authority on Transantiago, as well as its participation in the relevant committee sessions of the Chamber of Deputies.

Availing himself of the powers provided in Law 20,504, in 2015 Andrés Gómez-Lobo, transport minister of then-president Michelle Bachelet, began to reassign routes, mainly affecting large foreignfunded operators. By reassigning routes the authority was able to oppose the large companies without exposing itself to displays of their structural power. In other words, this resource was more accessible than forcing the expiry of contracts which, as we have seen, was an unfeasible alternative in the case of large companies due to the absence of backup services. However, as a business leader noted, the application of this new strategy "caused a lot of tension in the relations between the Chilean and Colombian operators" (interview with business leader n⿳3), with implications for ACTUS and the 
future course of action of the operators, which were already anticipating calls for tender of half of the business units planned for 2018. Thus, at the end of 2015, the operators decided to wind up ACTUS due to the internal tensions mentioned, because, as one expert put it, "the operators did not support Alsace-Express, simple as that. In other words, there was no community of interests "(interview with expert Once again, $\mathrm{n}^{\circ} 1$ ). Once again, company strategies vis-a-vis the authority diverged.

In the particular case of Alsacia-Express, the company faced a downturn in its financial situation. The system's current situation was marked by the search for a restructuring of its debt and bankruptcy risks. In the perspective of business power, the political handling of bankruptcy risk had not ceased to be a relevant factor. In effect, the companies Subus and then Alsacia Express went on to ask the minister directly for further changes in their contracts, mentioning that without them they could go bankrupt, and therefore leave important areas of the city without a transport service. They also threatened to resort to international arbitration, in this case the International Center for Settlement of Investment Disputes (ICSID). The authority did not yield to this pressure and finally the company Alsacia-Express filed a complaint against the Chilean state with the ICSID for "breach of the concession contracts" (Diario Financiero, 07-06-2017), that is currently under consideration.

This episode illustrates the tensions that can occur in a regulatory relationship, but also confirms how the financial (indebtedness) and legal (contract provisions) aspects need to be analyzed from a political point of view, and within the framework of a conflictual relationship. In analytical terms, the failed construction of an actor able to carry weight in the public discussion of transport is evidence of the weakness of the companies' instrumental power. Even so, the division between the operators shows the existence of alternative strategies. Some operators chose a particularly conflictive strategy while others, in line with the ambitions of ACTUS although without its unified approach, continued to pursue strategies aimed at building a long term relationship with the authority.

\subsection{Structural power again: a new bidding process and the restructuring of the relation between regulation and business power}

Almost 10 years after the start of the system, the process of re-assigning half of the business units came under consideration. From an analytical point of view, this scenario again changes the evaluation of the relationship between regulation and business power. In the new adjudication process, classic structural power made itself felt powerfully. Unlike the concern about the risk of bankruptcy expressed earlier and described above, in this stage the authorities' main concern, once again, was to attract investors.

In principle, the authority wanted to carry out a bidding process that differed from the first, for example by including an early stage of public consultation to identify the users' concerns. However, in this new process the challenge of attracting bidders emerged once more. For this purpose, roadshows were organized to present the project. Transport operators were convened but the main focus was on financial institutions, particularly foreign ones, to encourage them to fund the bidders. This highlights the weight of financial constraints on the relationship established in the framework of this regulatory process.

The new call for tenders just described takes us back to the bidding processes initiated in early 2000. With this new panorama, the traditional structural power observed during the first Transantiago bidding process re-emerged forcibly. Empirically, this can be seen in the conditions established in the concession contracts for the new bidders. Two main elements allow us to weigh the importance of 
structural power: the establishment of lenient criteria to attract new companies and the generation of conditions to ensure the participation of investors to guarantee the system's financial solvency.

Regarding the latter, the undersecretary at the time, Carlos Melo, had announced that the contracts could have a duration shorter than the 10 years of the first concessions. However, it was decided to maintain the duration unaltered, it being, according to Minister Tapia, "an interesting period for investors" (Pulse, 06-06-2017), as it provided greater security for recovering the initial investment. Here we can appreciate the structural power of the financial sector, and how the political authority has to take it into consideration, in general to the detriment of their preferences, in this case by adopting more flexible contracting process. Even so, the offers presented for tender were few, and included only three new foreign operators. Shortly before the awards were due to be made, the adjudication process was suspended by the Court for the Defense of Free Competition, which accepted a lawsuit filed by a small transport company alleging the existence of entrance barriers. Some weeks later, the new Minister Hutt, who was part of Sebastián Piñera’s new government, announced the cancellation of the new adjudication process, and its postponement pending reformulation. Even before the final outcome of this process is known, this third stage is revealing of the public actor's difficulty in counteracting the structural power of the private sector, even when the latter lacks instrumental power.

To synthesize the narrative, we present our evaluation of the three study hypotheses.

\section{TABLE 3 EVALUATION OF THE STUDY HYPOTHESES}

\begin{tabular}{|c|c|c|}
\hline Hypothesis & Evidence & Evaluation \\
\hline $\begin{array}{l}\text { H1a. Operators' } \\
\text { instrumental power }\end{array}$ & $\begin{array}{c}\text { The attempt by the operators to build cohesion } \\
\text { fails. They lack the tecnical expertise requested } \\
\text { by the authority and do not enjoy a good public } \\
\text { image. }\end{array}$ & $\begin{array}{c}\text { The operators show little instrumental power, } \\
\text { so this cannot be the factor that explains their } \\
\text { ability to resist the preferences of the public } \\
\text { actor. }\end{array}$ \\
\hline $\begin{array}{c}\text { H1b. Operators' structural } \\
\text { power }\end{array}$ & $\begin{array}{l}\text { Both in the original call for tenders as well as in } \\
\text { the new call for tenders, the authorities' main } \\
\text { concern is to make the concessions attractive to } \\
\text { investors, in particular from the financial sector. } \\
\text { During the concession, the bankruptcy risk } \\
\text { and in general the political risk of the service's } \\
\text { suspension is a highly effective instrument of } \\
\text { pressure. }\end{array}$ & $\begin{array}{l}\text { The structural power of the private actors- } \\
\text { operators and financial institutions-who } \\
\text { participate directly or indirectly in the system is } \\
\text { very important. It is the most important factor } \\
\text { in explaining the difficulties of the executive in } \\
\text { carrying out its preferred changes. }\end{array}$ \\
\hline $\begin{array}{l}\text { H2. Deficiencies of public } \\
\text { agencies and of the } \\
\text { authority }\end{array}$ & $\begin{array}{l}\text { Major deficiencies in the public authorities are } \\
\text { not apparent. The authorities are competent } \\
\text { and enjoy political support both from presidents } \\
\text { in office and from parliamentarians, who show } \\
\text { a surprising degree of unanimity. The financial } \\
\text { problems of the system are not a decisive factor } \\
\text { in the relationship with the operators. }\end{array}$ & $\begin{array}{l}\text { The alternative hypothesis is rejected as a } \\
\text { central explanatory factor in the process. If } \\
\text { the authorities are unable to impose their } \\
\text { preferences it is not because of their own } \\
\text { deficiencies. }\end{array}$ \\
\hline
\end{tabular}

Source: Elaborated by the authors. 


\section{CONCLUSION}

Through this case study of urban public transport regulation in Santiago, we have shown the importance of including the conceptual contributions of business power theory in a complete understanding of regulatory processes. Transantiago was one of the most publicly questioned policies in recent decades. The poor quality of service that was evident from its first day of operation inspired constant gradual contractual changes over more than a decade of the system's operation. In this context, the relations between transportation entrepreneurs and the political authorities, through the different public policy instruments in the matter of regulation, are fundamental to understanding the difficulty of modifying the regulation and the service itself.

Study of the Transantiago case clearly validates the premise that motivated this article. Although the practice of regulation is related to the contract design, political variables are fundamental in understanding the dynamics involved and the outcomes obtained. Thus any re-negotiation of a concession can be expected to be an opportunity for a power game between the different actors involved. Under that type of configuration, the analytical tools of political economy allow a full understanding of the courses of action adopted by the different parties. In this case, we concluded that the authorities were unable to impose their policy preferences on the system's operating companies, and this was not because the latter had a strong lobbying capacity, as is sometimes believed. In this case, the outcome was neither a result of deliberate action by the concessionaires-relatively weak in terms of instrumental power-nor of lack of state capacity. Rather, the explanation lies in the exercise of a structural power that was established from the system's origins and that is closely linked to its financing requirements. Thus, entrepreneurs' structural power is fundamental in explaining these dynamics of the regulatory policies of the urban transport system of Santiago. This creates the conditions for a later trajectory of "path dependence", which continues until the present day.

Additionally, we have been able to determine that this structural power was expressed in two ways, depending on the phase of the policy. On the one hand, structural power in its traditional form acted in the adjudication process, that is, policy-makers made decisions in the political sphere, safeguarding and promoting private investment (Fairfield, 2015a). On the other hand, in the adjudication phase, structural power could be seen behind the constraint of the regulatory authorities, a product of their expectations about the possible bankruptcy of the companies and the consequent disruption of the service that their regulatory decisions, as well as their sanctions, could entail.

Seen from this angle, the Transantiago case was a typical case of contractualization, so it is to be expected that similar dynamics, and in particular the force of structural power, will also appear in other situations of public-private collaboration. Taking these elements into account, the present study represents a contribution in at least two ways. First, it encourages the study of regulatory policies from analytical perspectives different from those traditionally used in disciplines such as public administration and law. The heuristic capacity of the theoretical currents used here demonstrates the importance of incorporating this type of analysis in complex political processes, where public and private actors develop different types of interaction depending on their often conflicting objectives. Second, the research has also managed to establish valuable lessons for contracting processes and for regulatory policies in general. Thus, the importance is clear of adding to the traditional tools of contract design these political concerns regarding the real applicability of sanctions, strongly limited as these are by the structural power companies hold. 


\section{REFERENCES}

Álamos, V. (2017). Poder empresarial y políticas públicas: el caso de las reformas laborales en el Chile post dictadura. (Master Thesis). Universidad de Chile, Santiago, Chile.

Athias, L., \& Saussier, S. (2007). Contractual flexibility or rigidity for public private partnerships? Theory and evidence from infrastructure concession contracts. Munich, Alemania: University Library of Munich.

Baldwin, R., Cave, M., \& Lodge, M. (2010). The Oxford Handbook of Regulation. New York, USA: Oxford University Press.

Bell, S., \& Hindmoor, A. (2013). The Structural Power of Business and the Power of Ideas: The Strange Case of the Australian Mining Tax. New Political Economy, 19(3), 470-486.

Besley, T., \& Persson, T. (2009). The origins of state capacity: Property rights, taxation, and politics. American Economic Review, 99(4), 1218-1244.

Besley, T., \& Persson, T. (2008). Wars and state capacity. Journal of the European Economic Association, 6(23), 522-530.

Bennet, A., \& Checkel, J. (2015). Process Tracing in the Social Sciences. From Metaphor to Analytic Tool. Cambridge, Reino Unido: Cambridge University Press.

Bhagat, G. (2017). Public Procurement: a Competition Perspective. Indian Journal of Public Administration, 63(2), 176-186.

Bitrán, E., Nieto-Parra, S., \& Robledo, J. (2013). Opening the black box of contract renegotiations: An Analysis of Road Concessions in Chile, Perú and Colombia. (Working Paper, 317). Paris, France: OECD Development Centre.

Bovaird, T. (2006). Developing new forms of partnership with the 'market' in the procurement of public services. Public administration, 84(1), 81-102.

Bril, T., Maillet, A., \& Mayaux, P.-L. (2017). Process tracing: inducción, deducción e inferencia causal. Revista de Ciencia Política, 37(3), 659-684.

Centeno, M. A. (2002). Blood and Debt: War and the Nation-State in Latin America. Pennsylvania, USA: Penn State Press.
Christensen, T., \& Lægreid, P. (Eds.). (2006). Autonomy and regulation: Coping with agencies in the modern state. Massachusetts, USA: Edward Elgar Publishing.

Cingolani, L. (2013). The State of State Capacity: a review of concepts, evidence and measures. (MERIT Working Papers, n. 53). Ámsterdam, The Netherlands: Institutions, Governance and Longterm Economic Growth.

Córtazar, R. (2015). Transantiago: 10 claves para enfrentar crisis. Santiago, Chile: Uqbar Editores.

Culpepper, P. (2011). Quiet Politics and Business Power: Corporate Control in Europe and Japan. New York, USA: Cambridge University Press.

Culpepper, P. (2015). Structural power and political science in the post-crisis era. Business and Politics, 17(3), 391-409.

Dente, B., \& Subirats, J. (2014). Decisiones públicasAnálisis y estudio de los procesos de decisión en políticas públicas. Barcelona, España: Ariel.

Engel, E., Fischer, R., \& Galetovic, A. (2010). The economics of infrastructure finance: Publicprivate partnerships versus public provision. EIB papers, 15(1), 40-69.

Espacio Público. (2017, enero). Transantiago: nueva licitación que abre oportunidades. (Informe de políticas públicas, 11). Santiago, Chile: Fundación Espacio Público.

Evans, P. (1996). El Estado como problema y como solución. Desarrollo Económico, 35(140), 529-562.

Fairfield, T. (2015a). Structural power in comparative political economy: perspectives from policy formulation in Latin America. Business and Politics, 17(3), 411-441.

Fairfield, T. (2015b). Private Wealth and Public Revenue in Latin America. Business power and tax politics. New York, USA: Cambridge University Press.

Figueroa, C., \& Forray, R. (2011). Transantiago: Convergencias y divergencias entre la vocación de servicio público y la racionalidad técnico-económica del sistema. La fabrique du mouvement.

Gilardi, F., \& Maggetti, M. (2011). The independence of regulatory authorities. In Levi-Faur, D. (Ed.). 
Handbook on the politics of regulation. Massachusetts, USA: Edward Elgar Publishing.

Girth, A. (2012). A closer look at contract accountability: Exploring the determinants of sanctions for unsatisfactory contract performance. Journal of Public Administration Research and Theory, 24(2), 317-348.

Goertz, G.; \& Mahoney, J. (2012). A tale of two cultures: Qualitative and Quantitative Research in the Social Sciences. New Jersey, USA: Princeton University Press.

Gómez-Lobo, A. (2007). Transantiago: una reforma en panne. TIPS, Trabajos de Investigación en Políticas Públicas, 4, 1-14.

Hacker, J., \& Pierson, P. (2002). Business power and social policy: Employers and the formation of the American welfare state. Politics \& Society, 30(2), 277-325.

Jordana, J., \& Levi-Faur, D. (2005). The diffusion of regulatory capitalism in Latin America: Sectoral and national channels in the making of a new order. The Annals of the American Academy of Political and Social Science, 598(1), 102-124.

Lindblom, C. (1982). The Market as Prison. The Journal of Politics, 44(2), 324-333.

Maillet, A. (2008). La gestación del Transantiago en el discurso público: hacia un análisis de políticas públicas desde la perspectiva cognitivista. In $\mathrm{M}$. De Cea, P. Díaz, \& G. Kerneur. (Eds.), Chile: de país modelado a país modelo. Una mirada sobre la política, lo social y la economía. Santiago, Chile: Gresch.

Maillet, A. (2015). Más allá del "modelo" chileno: una aproximación multi-sectorial a las relaciones Estado-mercado. Revista de Sociología E Política, $55,53-73$.

Mardones, R. (2008). Chile: Transantiago recargado. Revista de Ciencia Politica, 28(1), 103-119.

Menezes, F., Pitchford, R., \& Wait, A. (2003). Tendering and bidding for access: A regulator's guide to auctions. Australian Journal of Management, 28(3), 345-370.
Ministerio de Transportes y Telecomuinicaciones. (2003). Bases para la licitación del estudio. Santiago, Chile: MTT.

Mukhopadhyay, B. (2011). Evaluating public procurement. Review of Market Integration, 3(1), 21-68.

Olavarría, M. (2013). De la formulación a la implementación del transantiago. Análisis del Proceso Político de una Política Pública. Revista Gestión Y Politica Pública, 22(2), 355-400.

Osborne, D., \& Gaebler, T. (1992). Reinventing government: How the entrepreneurial spirit is transforming government. Reading Mass. Adison Wesley Public Comp, 33(6), 97-99.

Peters, G. (1996). The policy capacity of government. Ottawa, Canada: Canadian Centre for Management Development.

Ramírez, P., \& Minay, S. (2007). El recorte que mató al Transantiago. Santiago, Chile: CIPER. Retrieved from https://ciperchile.cl/2007/11/04/el-recorteque-mato-al-transantiago/

Skocpol, T. (1985). Bringing the state back in: strategies of analysis in current research. In P. Evans, D. Rueschemayer, \& T. Skocpol. (Eds.), Bringing the State Back in. Cambridge, Reino Unido: Cambridge University Press.

Stigler, G. (1971). The theory of economic regulation. The Bell journal of economics and management science, 2(1), 3-21.

Trampusch, C., \& Palier, B. (2016). Between X and Y: how process tracing contributes to opening the black box of causality. New Political Economy, 21(5), 437-454.

Ureta, S. (2015). Assembling Humans: Transport Infrastructures and the Dream of a World-Class City in Chile. Massachusetts, USA: MIT press.

Wettenhall, R. (2003). The rhetoric and reality of public-private partnerships. Public Organization Review, 3(1), 77-107. 


\section{Antoine Maillet}

iD

https://orcid.org/0000-0002-4607-3964

Doctor of Political Science; Assistant Professor of the Institute of Public Affairs of the University of Chile.

E-mail: antoinemaillet@iap.uchile.cl

\section{Sebastián Carrasco}

https://orcid.org/0000-0003-0081-2909

Doctorate student in Public Policy, Universidad Mayor; Master in Political Science from the Institute of Public Affairs of the University of Chile. E-mail: sebastian.carrasco.s@ug.uchile.cl 